\title{
Gender Disparities and Roles of Women in Agriculture in the South Eastern Nigeria
}

\author{
Udemezue $\mathrm{JC}^{1 *}$ and Odia $\mathrm{FN}^{2}$ \\ ${ }^{1}$ National Root Crops Research Institute, Nigeria \\ ${ }^{2}$ Department of Agricultural and Bioenvironmental Engineering Technology, Delta State Polytechnic, Nigeria
}

*Corresponding author: Udemezue JC, National Root Crops Research Institute, Umudike, PMB7006 Umudike Abia State, Nigeria

\section{ARTICLE INFO}

Received: 慧 June 10, 2021

Published: 幽 June 22, 2021

Citation: Udemezue JC, Odia FN. Gender Disparities and Roles of Women in Agriculture in the South Eastern Nigeria. Biomed J Sci \& Tech Res 36(4)-2021. BJSTR. MS.ID.005892.

Keywords: Gender Difference; Women; Agriculture

\begin{abstract}
Women play a significant role in food production and food security on agricultural enterprise. In most parts of rural Nigeria, division of labour within the households is gender specific and according to age. Men and women perform different roles; have unequal decision-making power as well as differences in access to land and control over agricultural productive resources. As a result of these differences, their views, needs, priorities and constraints to improving their productive potentials differ. This affects their various outputs even in agricultural development. Therefore, understanding of gender participation and constraints in food production, processing and marketing among rural farmers in the South Eastern Nigeria is important due to the current threat to food security as a result of the economic recession facing the country and this calls the need to increase and sustain the enterprise among farmers. This will ensure effective allocation of resources for increased and sustainable crop development activities, thereby increasing farming outputs for improved livelihoods for the people. Despite the important roles women play in family farming in Nigeria, they are hardly given any attention in the area of training and/or visitation by extension agents with improved technologies. Banks hardly grant loans to them and are rarely reached with improved seeds, fertilizer and other farm inputs. These conditions have placed the women in a vicious cycle of poverty and are highly disadvantaged in economic empowerment for agricultural development. In the light of this, the work addresses gender disparities among farmers, roles of women in agriculture, challenges of women in agriculture and the panacea for the problems.
\end{abstract}

\section{Introduction}

Agriculture is a prestigious, noble and lucrative profession that can no longer be left in the hands of novices and old people to be operating with crude implements. They make use of their human muscle and spent a lot of energy. There is improved technology in farming now but government needs to make more improvement in the areas of farm mechanization, provision of credit and modern storage facilities among many others. The issue of providing community empowerment through improved incomes to people living in rural communities has attracted some scholarly discussions due to the critical roles that community empowerment can have on improving and sustaining livelihoods for people, including women who find themselves in agriculture Yidana [1]. Women generally constitute a substantial part of the workforce in many developing countries and also a 43 percent of the global agricultural labour force Creswell [2]. Some literature have indicated that their involvement in agriculture is motivated by many factors including potential incomes from agriculture, secured employment, and provision of the livelihood needs of the people engaged in agriculture.

A study about women in agriculture in Ghana (Duncan, 2003), has found that women are among the most important actors in the food chain-that begins from farm production, market and intra household distribution of food. Women are particularly at 
the forefront of post harvest agricultural activities such as selling of grains, storage, processing and marketing. Women therefore remain as the centre-piece of efforts to address food security and also hold the key to a sound and healthy economy. Duncan (2003) argues that in spite of the central role that women play in promoting economic development of Ghana, women have much more limited access to resources than their male counterparts especially in the areas of education, land, agriculture extension and access to credit, all of which combine to restrain women's ability to increase their productivity and incomes. Afolibi [3] contends that women are very strong pillars of the economy of Ondo State in Nigeria as far as agricultural activities are concerned. It has been found that rural women in Ondo State are amongst the major contributors to food production and that these rural women have contributed a lot to the management of human and economic resources to achieve optimum results Brown [4]. They maintain that the output from the farms of these rural women particularly contributes to food production that addresses food shortage crises. It is important to add those women who engage in the cultivation of staples such as cassava are significantly predisposed to improved incomes that tend to positively impact on the livelihood stakes of people in the rural communities.

Gender is a term often associated with roles and responsibility of males and females in the society as a social classification of sex. It is the socio-cultural differences between males and females as against the biological differences (Sinkaiye \& Jibowo, 2005). It is also described as a concept used in social science analysis to look at roles and activities of men and women (International Institute of Tropical Agriculture (IITA, 1996). Thus, the focus of gender analysis is not biological differences between men and women but rather on their experiences as members of society. Gender participation give insight into issues affecting women and it is focused mainly on the relationship of both men and women to the social and economic structure of a society Mary 0 Agada [5]. In most parts of rural Nigeria, division of labour within the households is gender specific and according to age. Men and women perform different roles; have unequal decision-making power as well as differences in access to land and control over agricultural productive resources. As a result of these differences, their views, needs, priorities and constraints to improving their productive potentials differ. This could affect their various outputs even in agricultural development. Hence, the understanding of gender participation and constraints in food production, processing and marketing among rural farmers in the South Eastern Nigeria is important due to the current threat to food security as a result of the economic recession facing the country and this calls the need to increase and sustain the enterprise among farmers. This will ensure effective allocation of resources for increased and sustainable crop development activities, thereby increasing farming outputs for improved livelihoods for the people Mary O Agada [5].
Rural women play a vital role in food production and food security on family farms and as paid or unpaid laborers on other farms and agricultural enterprises (Ahmed and Maitra, 2010). Rural women are involved in both crop and livestock production at subsistence and commercial levels. They produce food and cash crops, providing two thirds of the food crops and manage mixed agricultural operations Food and Agriculture Organization (FAO) [6]. Rural women are also known to be fully involved in all operations of farming such as planting, thinning, weeding, fertilizer application, harvesting, storing, processing and marketing Mybada [7]. They contribute between $40 \%$ and $60 \%$ of all hours spent in agricultural production and processing and also undertake $60 \%$ to $90 \%$ of the rural agricultural products marketing, thus providing more than two thirds of the workforce in agriculture Soubh [8]. Olawoye [9] reported that $97 \%$ of women in Oyo State were involved in weeding (97\%), processing (92\%), transportation (91\%), marketing (79\%) planting (50\%) and harvesting (35\%). They are also involved in collection of fuel wood and water, caring for family members and maintaining their homes. This implies that women in all ramifications play roles for social and economic development of rural households.

Despite the dominant and important roles women play in family farming in Nigeria, they are hardly given any attention in the area of training and/or visitation by extension agents with improved technologies. Banks hardly grant loans to them and are rarely reached with improved seeds, fertilizer and other farm inputs Damisa, et al. $[10,11]$. These conditions have placed the women in a vicious cycle of poverty and are highly disadvantaged in economic empowerment for agricultural development. In the light of this, the work addresses gender disparities and roles of women in agriculture in Anambra State Nigeria.

\section{Roles of Women in Agriculture}

Women play a central role in crop production, processing and marketing, contributing about $58 \%$ of total agricultural labour in the south west, $67 \%$ in the southeast and 58\% in the central zones. However,they almost entirely responsible for virtually all the activities like ridging, planting, weeding, harvesting, transporting, sorting, processing, marketing and domestic chores which provides them with additional income-earning opportunity to enhance their ability to contribute to household food security Mgbako [12]. Rural women are involved in both crop and livestock production at subsistence and commercial levels. They produce food and cash crops, providing two thirds of the food crops and manage mixed agricultural operations, involving crops, livestock and fish farming that considered as part of the agricultural laborforce Food and Agriculture Organization (FAO) [6]. Rural women contribute between $40 \%$ and $60 \%$ of all hours spent in agricultural production and processing and also undertake $60 \%$ to $90 \%$ of the rural agricultural products marketing, thus providing more than 
two thirds of the workforce in agriculture Soubh, et al. $[8,11]$. According to Olawoye [9] in Mbah [11] reported that $97 \%$ of women in Oyo State were involved in weeding (97\%), processing (92\%), transportation (91\%), marketing (79\%) planting (50\%) and harvesting (35\%). They are also involved in collection of fuel wood and water, caring for family members and maintaining their homes. Many of these activities are not defined as economically active employment but they are essential to the well being of rural households.

An understanding of gender contributions to food output in rural households in Nigeria is important. This will ensure effective allocation of production resources within the rural households. Given equal opportunities to both men and women will increase the farm output of the households and improve their standard of living. Numerous studies indicate that rural development policies directed at the household may not have their intended effects or produce unintended negative outcomes, unless the role and position of gender in rural households are explicitly taken into account Chinasaokwu [13]. Women in Nigeria form an active and reserve labour force but they rarely own the means of productions Rahman [14]. However, the position of women in meeting challenges of agricultural development cannot be over emphasized. Women make a significant contribution to food production; they provide $60-80 \%$ of agricultural labour and are responsible for $80 \%$ of food production Rahman [14]. Socio-economic and political obstacles have for long been intensifying gender inequality and exacerbating poverty among women Rahman, et al. $[13,15]$.

In rural settings, the contribution of women in agriculture should not be faced with irony and mirage. Women contributed most especially in all facets of agriculture except where culture and norms placed barrier from their participation. In Anambra State to be specific, women contributed about $55 \%$ of work force of farming activities. They engaged seriously in farming activities like; land preparation, planting, weeding, fertilize application, processing of agricultural produce like rice and cassava into gari and fufu. Women in cassava processing have a high potential to contribute effectively to income generation and the livelihood status of their families. The need to improve the sources of raw materials and modes of processing cassava products is important as this will help to improve the livelihoods for women and in general people involved in the cassava industry in many rural communities Mbah [11]. They participated heavily in farming of crops like rice, okro, sweet potato, cowpea, cassava, melon and maize with exception of yam where gender barriers restricted them from planting it. The major crops grown by women in Omor community are okro, sweet potato, maize, cassava, rice, melon and vegitables. Yam production is left for men alone except in weeding where women's complementary effort is needed. This is done because of simple belief that women are culturally restricted from planting yam as their major crop. This unequally distributed farming activity in the area brings about food shortage to the teaming population. However, if equal opportunity could be given to all farmer in the area, that is allowing both men and women to grow whatever crops he/she wants to crop without gender disparity, there is tendency to boost food security in the south east and Nigeria in general.

\section{Challenges of South Eastern Women in Food Production}

Agriculture is the world's oldest profession. This was referred in the book of bible, Genesis chapter9 verse 20 where Noah was recognized as the first man on earth to plant in the vine yard. Therefore, there is need to farm in order to fight hunger and poverty. Nature has placed food and water at the second list after air in order of importance and services in the world. In order of priority, nature has made this ranking a necessity of life. Food is the product of agriculture and water and from biological perspective; water is one of the classes of food Nnebedum [16]. Therefore we must embrace agriculture at all cost to sustain life and progress. Under male dominated social structures and political systems, women do not derive equal access to land, technology, education and resources Tanko [17]. The problem of food shortages in Nigeria has been attributed to an acute dearth of gender equality and a shift of farm responsibilities to the women Uwadie, et al. $[13,18]$. There has also been a great disparity between women and men in the size of land holdings as well as any overall trend of increasing landlessness pressure. In the light of these, the key constraints affecting women's ability to improve efficiency in agriculture in the South East include.

\section{Lack of Access to Loan}

In Nigeria, women farmers receive less than $10 \%$ of the credit offered to small-scale farmers. Women farmers are deterred from applying for formal loans because of the complexity of the administrative process, unsuitable loan sizes and credit rates [19]. According to the National Bureau of Statistics, in 2007, some 20,098 men accessed loans compared to 8,550 women. These aforementioned problems affect women who want to go into farming in Omor community.

\section{Lack of Access to Information and Training}

Women participation in farmer training is low due to the lack of awareness, society barriers, and transportation facilities. Women farmers in this community do not participate fully in agricultural training due to some of them may not be aware of the training. There is need to disseminate information across to everybody through town crier and radio station [20].

\section{High Cost of Farm Inputs}

Because of the poverty level in some rural areas, women are unable to buy agricultural inputs such as improved seedlings and fertilizer. Women farmers have indicated that they are unable to use inputs due to high cost in the open market. 


\section{Land Ownership}

Women in the community generally own less land due to traditional authority. Women's access to land is dependent on their husbands or fathers. Supplementary land is rented by both women and men from other families, provided they can afford the costs. According to the 2012 Gender report in Nigeria by the British Council, women own $4 \%$ of land in the North-East, and just over $10 \%$ in the South-East and South-South has less than $10 \%$ of land allocated to women [21]. Therefore, lack of land ownership significantly reduces the chances for women's access to produce enough food due to limited land assigned to them. Sequel to this, farmers in the area said that the major factors that constrain women involvement in cassava production and processing in the community are non-ownership of farm land, their pre-occupation with household chores, inadequate farm size, as well as high cost of processing cassava roots into the granular-like form called garri.

\section{Conflicts and Civil Insecurity}

The spread of communal war and conflict interrupted production of food and displaced people leaving fertile land uncultivated. Also, there are occasional communal crisis that has had devastating effects on the community economic development especially in the area of food production. Other conflicts may take the form of physical fighting, structural violence without declaring war which may result from premeditated pervasion of poverty, rich oppression of the poor, police brutality, intimidation of the common citizens by politicians, women and children oppression and monopolization of resources and power.

\section{Climate Change and Natural Disasters}

Global climate change is another important driver of food insecurity that cannot be overlooked. Climate change is responsible for biodiversity loss in the ecosystem as well as other physical access. It has become one of the key factors that is redefining the global food equation and thus having so much impact on the food security of developing nations. Natural disasters and climate variability constitute other key factors making people from less developed nations vulnerable to food insecurity. The impact of such phenomenon as drought, flood and land slide is more pronounced in regions where agriculture highly depends of rainfall. While drought and land slide constitute a major threat for the food availability, excessive rain or flood has had a significant impact on the current hike in food prices.

\section{Lack of Technology for Processing and Storage}

The use of modern technologies in the production and distribution of agricultural products is very low in the community so the farmers depended more on manual labour for farm activities. This is because of lack of innovation in local technology, particularly as it relate to mechanization of agriculture to improve productivity.
Local farmers can hardly afford imported technologies and lack maintenance capacity. Inadequate or lack of facilities to preserve food items such as cereals, yam, beans, etc. can result in wastage thereby further deepening the insecurity level of food. Also, lack of food processing apparatus sometime leave farmers with no choice than to consume significant fraction of their harvest within short period. Food processing is an important aspect of agriculture that prevents wastage of food items that cannot be easily stored in their original form by transforming them into other form that can enable their preservation. To achieve a sustainable food security, effort must be made to avert any wastage.

\section{Gender Inequality}

Gender inequality is one of the primary driving forces of food insecurity because this is the most important concern of people who are denied access or unable to engage in labor. Women face lots of discrimination both in seeking education, land for cropping and job. They face similar fate even at home within the household, yet women are mostly responsible for preparing meals and taking care of the children. They mostly spend all or a good fraction of their income on feeding and their children's needs. The role of women in ensuring adequate land use, as well as food production, processing, distribution and marketing cannot be over emphasized. Women often deprived of access to agricultural assets, inputs and service when compared to men. Analysts, have suggested that if women where to have the similar access as men to productive resources, yield would increase by $20 \%$ - 30\%, boosting the total agricultural output by $2.5 \%$ to $4 \%$ in developing countries. If gender inequality is minimized and women are given better access to agricultural facilities, achieving food security will be much easier. It has been established over time by raising women's status, poverty will decline and nutrition will be enhanced.

\section{Panacea for the Problems}

Despite the dominant and important roles women play in family farming in Nigeria, they are hardly given any attention in the area of training and/or visitation by extension agents with improved technologies. Banks hardly grant loans to them and are rarely reached with improved seeds, fertilizer and other farm inputs. These conditions have placed the women in a vicious cycle of poverty and are highly disadvantaged in economic empowerment for agricultural development. Development policy makers and planners are becoming increasingly aware of the crucial contributions of women farmers to agricultural production and food security.

As a result of the above, these call for solutions as follows: Nigerian government at all various levels should pay more attention to development of agriculture thereby breaking the gender barriers in some community. Honest implementation of all agricultural programm budgets should be in focus. The era of lip-service to 
agriculture by government and youths should be the thing of the past. Let us face the reality and once more place agriculture in the priority list as the mainstay and backbone of Nigerian economy. It is highly recommended that the women should belong to cooperative associations, and link with agricultural extension agents in their area. Further, there is need to review the existing land tenure system in the area and give women greater access to and control of production resources. Total harmonization of the both men and women in farming activities is a road map to agricultural sustainability and food security. Placing gender inequality among farmers in terms of crop production will not only create a lacuna in the field of agriculture but also will subject the people to hunger and starvation. Therefore, if men harmonize their efforts just like women towards those minor crops like sweet potato, cassava, maize among others, this will ward off hunger in the state and also make the State a food basket of the nation. More so, closing the gender gap in agriculture would produce significant gains for society by increasing agricultural productivity, reducing poverty and hunger, and increasing economic growth of the nation.

\section{References}

1. Yidana JA, Osei-Kwarteng M, Amadu Y (2013) The impact of cassava processing on the livelihoods of women processors in Central Gonja district of the northern region of Ghana. African Journal of Agricultural Research 8(49): 6524-6528.

2. Creswell J (2003) Research Design: Qualitative, Quantitative, and Mixed Methods Approaches. London: Sage Publications.

3. Afolabi MM (2008) Women as pillars of national economy in Nigeria: A study of economic activities of rural women in six local government areas of Ondo State. IAFFE Summer Conference, International Association for Feminist Economics, Torino, Italy.

4. Brown LR, Feldstein H, Haadad L, Pena C, Quisumbig A (2001) Women as producers, gatekeepers and shock absorbers, In: PP Anderson and R Pandya-Lorch (Eds.)., The Unified Agenda-Perspectives on overcoming Hunger, Poverty and Environmental Degradation. DFID Livelihoods Guidance.

5. Agada MO, Onuche FI, Mbah EN (2018) Gender Participation and Constraints in Cassava Production, Processing and Marketing in Makurdi, Benue State, Nigeria. International Journal of Gender and Women's Studies 6(1): 79-87.

6. (2011) Food and Agriculture Organization (FAO). Women in Agriculture - Making a Strong Case for Investing in Women. Rome: FAO, p. 56-60.

7. Mybada JU (2000) Production of stable crops by rural women in Enugu and Ebonyi States. Lessons for enhancing poverty alleviation programs.

\section{ISSN: 2574-1241}

DOI: 10.26717/BJSTR.2021.36.005892

Udemezue JC. Biomed J Sci \& Tech Res

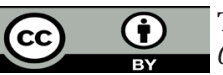

This work is licensed under Creative Commons Attribution 4.0 License

Submission Link: https://biomedres.us/submit-manuscript.php
8. Soubh S (2006) Women's role in Agriculture and gender related issues in Syria. National Agricultural Policy Centre (NAPC) Working paper No.18, p. 50-55.

9. Olawoye JA (2000) Difficulties for Rural African Women to Secure Access to Resources for Agricultural Production. Two case studies from Oyo State, Nigeria 3(2): 60-75.

10. Damisa M, Samdi R, Yohanna M (2007) Women Participation in Agricultural Production: A probit analysis. Journal of Applied Sciences $7(3): 412-414$.

11. Mbah EN, Saror SF, Agada MO (2016) Contributions of Rural Women to Family Farming in Benue State, Nigeria: Implications for Agricultural Development. International Journal of Trend in Research and Development 3(4).

12. Mgbako M, Nwamba HO (2013) The Role of Women in Cassava Production in Awgu L.G.A, of Enugu State, Nigeria. American-Eurasian Journal of Agronomy 6(1): 19-24.

13. Chinasaokwu SO (2012) Analysis of Women Participation in Cassava Production and Processing in Imo State, Southeast Nigeria. Journal of Economics and Sustainable Development 3(5): 81-90.

14. Rahman SA (2004) Gender Differential in Labour Contribution and Productivity in Farm Production Empirical Evidence from Kaduna State of Nigeria. Paper Presented at the National Conference on Family held at New Theatre Complex. Benue State University, Makurdi, Nigeria. $1^{\text {st }}-5^{\text {th }}$ March.

15. Rahman SA, Aruna IM (1999) Determinants of Women Economy Contribution to the Farm Sector in Nasarawa State, Nigeria. A Paper Presented at the National Workshop of Society for International Development held at: Institute of Administration, Ahmadu Bello University, Zaria, Nigeria.

16. Nnebedum L (2020) Career opportunities in agricultural profession. Fides News Paper 28(36): 11-17.

17. Tanko NM (1994) Contribution of Rural Women to Agricultural Planning and Economics of Developments in Nigeria, In: Ikpi A E and Olayemi J K (Eds.)., Winrock International for Agricultural Development, p. 5-6.

18. Uwadie SA (1993) Mechanisms for Improving the Effectiveness of TIV Women's Participation in Agriculture through Farmer Education. UNN Nigeria; PhD Dissertation.

19. Ghana Statistical Service (2014). Population and Housing Census 2010 District Analytical Report, Kintampo North District, Accra: Ghana Statistical Service.

20. Arthur JL, Kwarteng P, Dorinaa E (2016) Developing community livelihoods: The case of women in cassava farming in the Kintampo North and South Districts of Ghana. Stu international Journal of Technology.

21. Karl M (2005) Inseparable: The crucial role of women in food security revisited. Women in Action, p. 1-12.

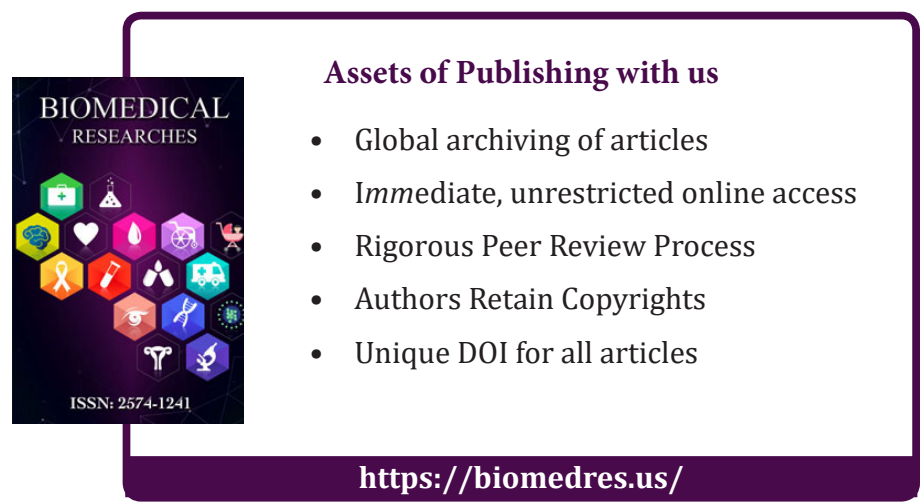

